\title{
The rise of Islamic Jihad in northern Nigeria and its implications on the Jos-Plateau religious conflicts
}

\author{
Jock Matthew Agai \\ School of Religion, Philosophy and Classics, University of Kwa-Zulu Natal, South Africa
}

Email address:

leadershipserve@yahoo.ca

To cite this article:

Jock Matthew Agai. The Rise of Islamic Jihad in Northern Nigeria and Its Implications on the Jos-Plateau Religious Conflicts. Social Sciences. Vol. 3, No. 3, 2014, pp. 67-73. doi: 10.11648/j.ss.20140303.11

\begin{abstract}
For over two decades, the regions of northern Nigeria have been experiencing various religious conflicts and government approach in curbing the menaces have often been of no positive effect. From the year 2001, the conflicts have taken a new dimension because Hausa/Fulani jihadists sporadically attack rural communities within the Jos Plateau province repeatedly killing hundreds and thousands of people without showing any remorse. The conflicts have often been described by the media and politicians as strictly an ethnic or land-ownership conflicts. Using historical analogies, this researcher argues that the course for Islamic Jihad in northern Nigeria which started since 1804 is the main reason behind Muslim and Christian conflicts in Jos.
\end{abstract}

Keywords: Holy War, Indigene, Jihad, Jos, Middle-Belt, Northerner, Northern Nigeria

\section{The Rise of Islamic Jihad}

Since the end of the sixth century AD, the Prophet Mohammed (peace be unto him) was dissatisfied with the Christians he met in Arabia most of whom were exiled from the Byzantine Empire due to their heretic views on reconciling Christ's humanity and divinity. Mohammed's dissatisfaction with the Jews came up because he was unfulfilled on the reconciliatory aspects between the Old Testament and the New Testament hence he began to preach a new faith (Sookhdeo 2002:10-11). The rulers of Mecca in particular began to persecute Mohammed and his converts. Pressure was mounted on the Prophet and he left Mecca for Medina where he was welcomed because there were internal strife in Medina and the people thought a strong leader was coming to unite them. The movement from Mecca to Medina took place in $622 \mathrm{AD}$ and is referred to as the Hijrah. Muslims marked this day as the beginning of the Muslim era and calendar (Agai 2003:3). ${ }^{1}$

\footnotetext{
${ }^{1}$ In order to procure successful opportunities for his new faith, Prophet Mohammed needed to gain acceptance by the Jews who were very influential in Arabia and in Medina. He introduced certain religious practices that were pleasing to the Jews. For example, he made the $10^{\text {th }}$ day of the month of Islamic calendar Moharan a day of fasting just like the Jews who normally fast on the $10^{\text {th }}$ Day of Atonement. He also introduced Noon prayers to his followers just like the Jews who prayed at noon day; the Prophet asked his followers to pray facing Jerusalem just as the Jews did and pilgrimages were
}

Through kindness, giving, verbal persuasions and military strength, Mohammed's followers took on the cause of Islam to many parts of the world and they penetrated North Africa sometime around 702 through 708 AD (Skolfield 2001:142). It is from North Africa that Islam found its way into West Africa.

The religion of Islam initially came into Nigeria in the eleventh century when the king of Kanem, Humai was converted. ${ }^{2}$ Business merchants from Mali brought alongside their Islamic faith during their business trips (Falola \& Heaton 2010:29). The faith was first concentrated at Njimi where many merchants from Mali settled before spreading to Ngazargamu (Omolewa 2008:90). The relocation of the Saifawa dynasty to Ngazargamu led to the establishment of Borno state and it was from here that Islam began to spread west to other Hausa states. A more radical impacts of Islam was felt in the Hausa states of Nigeria from the fourteenth century via the trading activities of the Wangarawa traders who also came from Mali (Falola \& Heaton 2010:29). At that time, not many

done in Jerusalem by his adherents likewise the Jews. He designed mosques in Medina in the pattern of Jewish synagogues. After the prophet gained more followers and after the Hijrah, he changed the fasting days from Moharan to Ramadan that is from the $10^{\text {th }}$ day of the first month to the ninth month. He asked Muslims to pray facing Mecca and not Jerusalem (Adamu 2002).

${ }^{2}$ Christianity on the other hand emerged in Nigeria since 1485 (Omolewa 2008:60, 80,143). 
Hausas accepted Islam as their faith yet those few Hausas who accepted Islam as their main faith mixed their traditional beliefs together with Islam. Omolewa (2008) says that those Hausas accepted Islam mainly for its economic gains and for the fact that there were internal strivings among some Hausa people hence they thought Islam was going to unite them (Omolewa 2008:92-93). The practicing of Islam together with some Hausa traditions or paganism by many Hausas in northern Nigeria became worrisome for Uthman dan Fodio who thought that Islam needed to be reformed or purified. ${ }^{3}$

Uthman dan Fodio born on $15^{\text {th }}$ December 1754 to Fulani parents lived his youthful life at Degel in northern Gobir. He belonged to the Qadiriyya which was the largest Sufi brotherhood (Tariqa) in West Africa at that time (Omolewa 2008:112). Uthman dan Fodio was known to have been a kind, generous, patient and a well learned young man who was mentored in Koranic disciplines by firstly his father, and later Uthman Bindin and finally by Jibril Ibn Umar. Umar was exiled from his country Agades for his radical approach to Islamic teachings. From 1774, Uthman dan Fodio travelled to many Hausa states including Zamfara and Gobir teaching and preaching about the need to adhere to strict Islamic tenets and he preached that the Sharia law ${ }^{4}$ be applied by all Muslims. He publicly accused Hausa leaders who claimed to be Muslims yet were not practicing Islam properly. A ruler in Degel by name Nafata was threatened by the popularity enjoyed by dan Fodio and between 1794 and 1795, Nafata introduced measures to curb the influence of dan Fodio in Degel and some of these measures included the banning of Muslim dress, turban, and veil (Omolewa 2008:111-112, 117).

Yunfa, Nafata's successor was more hostile against the disciples of dan Fodio and as a result Yunfa commanded dan Fodio to leave Degel. On $21^{\text {st }}$ February 1804 dan Fodio migrated from Degel to Gudu and his followers considered this movement as a Hijrah, similar to Prophet Mohammed's movement from Mecca to Medina. This event made dan Fodio to proclaim Jihad; he asked his followers to take up arms and wage war against unbelievers or infidels and this marked the beginning of formal Islamic Jihad in the whole of West Africa. Sometime in June 1804, Yunfa and his armies where defeated at the battle of Tabkin Kwotto and afterwards, Kano, Katsina and Daura were captured in 1808. The Jihad continued throughout Zaria until about 1812, after which Gombe, Bauchi, Adamawa, Gwandu, Nupeland, Kebbi, Niger-Benue confluence and parts of Yorubaland (Ilorin) were captured but they could not succeed in capturing Kanem-Borno until later stages (Omolewa

\footnotetext{
${ }^{3}$ For example, the Gani Festival in the Hausa states was celebrated as a New Year festival where informal sexual license was given to participants and there was an exchange of men and women for sexual gratification (Lange 2004:176$180)$.

${ }^{4}$ The Sharia laws are strict Islamic tenets which define mainly a pattern of societal life style for Muslims. The laws involved a combination of decision of religious leaders [ijma] + a guided reasoning [qiyas] + the Holy Quran + Hadith (Agai 2003:5-6)
}

\section{8:111-112, 117).}

The reasons and the successes for the Nigerian Islamic Jihad have been attributed to many factors including economic and social. Uthman dan Fodio accused the then Hausa traditional government of imposing heavy taxes upon the masses and he regarded the hudud (a form of legal penalties where the stratified rich class were not punished for crimes they committed) as a high form of injustice. Peasant farmers were also taxed heavily yet government rulers were living luxurious lives styles and were corrupt, unjust, they owned slaves, likewise they were not willing to attend to the plights of the masses. He, dan Fodio also condemned the rule where by only the eldest son of a family could inherit wealth and property; he demanded that all children of a deceased deserve to inherit wealth and property. These kinds of messages of social justice and equality preached by dan Fodio appealed to the masses or the poor people (talakawa) such that they took up arms in support of the teachings of dan Fodio (Omolewa 2008:113114).

The Fulani people who lived in Hausa land were regarded as settlers; they were not part of the government of Hausa land; they were not allowed to own slaves or carry arms and were made to pay heavy tax for their cattle (jangali), sometimes their cows were seized by Hausa leaders without compensation. On the other hand, the Fulani people saw themselves as a superior race because they were learned and received Islam earlier from other regions of Africa before the Hausas did so in Nigeria; their high regard for their race as a superior race made them not to intermarry with the Hausa people. Many Fulani people supported Jihad not because they were strictly Muslims but for racial, political, and linguistic reasons. This is why the Fulani factor serves as another reason why the Fulani ethnic group supported dan Fodio who was one of them (Omolewa 2008:114). The Islamic Jihad of dan Fodio was also a political movement, and his intention was seemingly to overthrow the government whom he taught were corrupt and oppressive. The demand by dan Fodio and his followers that strict Sharia law be practiced suggests that Islamic Jihad was political as well. In 1788, dan Fodio asked for some concession from Bawa the king of Gobir where he would be allowed to preach without being deterred. Omolewa (2008) says that this request made by dan Fodio had political implications because he asked that his followers wearing turban and veils be allowed and that all political prisoners be freed (Omolewa 2008:114-115).

Furthermore, dan Fodio might have carried out the Jihad for religious reasons which include adherence to the spread of Islam and in compliance to observing Islamic tenets as inscribed in the Holy Quran:

$$
\begin{gathered}
\text { Fight in the cause of God } \\
\text { Those who fight you, } \\
\text { But do not transgress limits; } \\
\text { For God loveth not transgressors. } \\
\text { And slay them wherever ye catch them, }
\end{gathered}
$$




\section{And turn them out from where they have Turned you out}

(The Holy Qur'an, chapter 2 verses 190,191).

Uthman dan Fodio called on his followers to use force to take over lands occupied by infidels, Dar al-Harb and turn those lands into the lands of the faithful Dar al-Islam (Omolewa 2008:116).

Since the introduction of Islamic Jihad by Uthman dan Fodio, Nigeria had at several stages experienced various religious conflicts. For example, the Maitatsine uprising started in Kano in 1980, the members of the Maitatsine sect thought that Muslims were not practicing pure Islam hence the need for reform; their extreme approach to Islamic evangelism had led to the killings of many Christians including the killing of some Muslims whom they thought were not living the lives of true Islam. The Jama'atu Ahli's Sunna Lidda'awati Wal-Jihad also known as Boko Haram is another Islamic sect which existed since 1995 and one of the aims of the sect is to purify Islam by fighting Christians, the Nigerian government and some Muslims whom they think were not living according to Islamic standards. Boko Haram's harsh response to civilians and the Nigerian government began in Bauchi from $24^{\text {th }}-28^{\text {th }}$ July 2009 and it spread to other parts of northern Nigeria. The members of Boko Haram have burnt several Churches and have killed many Christians (Je'adayibe \& Kudu 2013:5, 10-12; cf. Rothfuss \& Joseph 2012:80). Top Islamic clerics like Ahmed Ibrahim Abdullahi, Liman Bana, etc, and many Muslim politicians like Alhaji Modu Gobi, Modu Binbute and many more were killed by members of Boko Haram as well (Aliogo 2012:10-11).

The question arises on the Islamic legitimization and of the meaning of Jihad. The word jihad in the Quran and Hadith is derived from the root $j h d$ whose primary meaning is to strive or to exert oneself in the paths of Allah (Nasr 2006). In other words, Jihad means to "fight in the path of God."5 Nasr (2006) explained that the west have misguided many Muslims and others on the true meaning of Jihad by emphasizing what he termed the lesser Jihad (which involves the maintaining and enforcing of order in the society by adhering to strict Islamic tenets) means. Nasr (2006) says that Jihad has spiritual significance which involves one's vertical relationship with God and in keeping to the pillars of Islam and the Sharia law; he referred to this concept as inner Jihad:

Through inner jihad the spiritual man dies in this life in order to cease all dreaming, in order to awaken to that Reality which is in the origin of all realities, in order to behold that Beauty of which all earthly beauty is but a pale reflection, in order to attain that peace which all men seek but which can in fact be found only through inner jihad (Nasr 2006:6).

However, Nasr (2006) admits that lesser Jihad has echoed more throughout history because of agencies which

\footnotetext{
${ }^{5}$ Originally quoted by Bennett Clinton in Firestone R. Jihad: The Origin of Holy War inIslam (Oxford: Oxford University, 1999, pp. 195
}

stood against the wishes of Islam. He did not condemn those who take up arms to fight for Jihad rather he emphasized the need for Muslims to concentrate more on building their personal relationships with God. Many Muslims around the world are against the idea of taking up arms to fight for God:

For man to raise his hand against man, for man to kill man is not holy war. True holy war is to praise God and cut away the enemies of truth within our hearts. We must cast out all that is evil within us, all that opposes God. That is the war that must be fight (Muhaiyadden 1990:68).

However, it is pertinent to note that the rise of Islamic sects like Boko Haram, Maistasine, Al-Qaida, Alshabab, and many more all goes to suggest that where there is high threat to Islam, military strength may legally be implored.

\section{The Entity "Nigeria"}

Nigeria is a multi-cultural and multi-religious country with over 250 ethnic groups. The population of Nigeria is over 150 million making it the most populous nation in Africa and the eighth most populous nation of the world. Nigeria is divided into six geopolitical zones and the northern region of Nigeria has 19 states or provinces over the southern region which has 17 states (cf. Aliogo 2012:20, 26). The three main tribes according to the size of their population in Nigeria are the Ibos, the Yorubas, and the Hausas. Hausa language is the lingua franca in northern Nigeria yet there are many other tribes that exist in northern Nigeria apart from the Hausas, some of these tribes include: Berom, Babur, Tiv, Idoma, Igala, Jukun, Gwari and many more. The region of northern Nigeria is mainly a host to Muslims, Christians and African traditionalists.

Furthermore, understanding population size in northern Nigeria according to religious divides has always been a complex subject and that is why religious affiliation is not often considered in Nigeria's population census (Rothfuss \& Joseph 2010:42). In their earliest write-up, Rothfuss \& Joseph (2010:43, 50) clearly figure out the difficulties experienced in ascertaining the religious affiliations of the Nigerian population and they said that the subject is subject to contestation. Two years later, Ruthfoss \& Joseph (2012:76) say that the population of Christians outnumbered Muslims in northern Nigeria:

Indigenous Christians abound in large numbers in all the northern states. In at least seven of the 19 northern states Christians are the majority. North-western and northeastern regions have the largest concentration of Muslims. The north-central, which is also referred to the Middle Belt, considerably mixed with a Christian majority.

While this researcher applauds Ruthfoss \& Joseph for correcting a myth on the wrong demographic divide which describes northern Nigeria as a Muslim region and the southern parts of Nigeria as a Christian region, this researcher however question their motive that Christians are majority especially in northern Nigeria. Ruthfoss \& Joseph (2012:76) did not state the criteria they used in 
making this assertion and they did not point at the source where they obtain the information that Christians are the dominant religious groups in Nigeria. In northern Nigeria, there is yet to be found a clear and an unbiased report on the specific dominancy of any of the three major Nigeria's religious groups (Christians, Muslims \& African Traditional Religion).In other words, none of these three religious groups is majority in northern Nigeria until scientifically proven.

Before the name Nigeria became commonly used in the early 1800 s, each geographical zone existed independently. A British journalist and reporter for the London Times Newspaper, Flora Shaw, was the first to use the name Nigeria. On 8 January 1897, she reported:

As the title 'Royal Niger Company's Territories' is not only inconvenient to use, but, to some extent, is also misleading, it may be permissible to coin a shorter title for agglomeration of pagan [southern parts] and Mohammedan states [northern parts] which has been brought, by the exertions of the Royal Niger Company, within the confines of a British Protectorate and thus need for the first time in their history to be described as an entity by some general name (Omolewa 2008:12).

Frederick Lugard, a British Brigadier-General who later married Flora Shaw admired Shaw's suggestion, so on 1st January 1900; Lugard gave the name northern Nigeria to the region occupied by the Royal Niger Company. In 1912, an editor of the African Mail, E. D. Morel published a book entitled Nigeria: Its Peoples and Problems (Omolewa 2008:12). The works of Shaw, Lugard and Morel made Nigeria well known. The annexation of Lagos in 1861 through the declaration of two separate protectorates which were amalgamated on 1st January 1914 made the country to be formally called "Nigeria" (Murray 1981:147).Murray (1981:147) believes that the amalgamation of the various regions of Nigeria was to provide for equal opportunities for all the citizens of the protectorates and:

largely to balance the administrative deficits in the north with the surpluses from the south. Despite the amalgamation, the two halves [northern and southern Nigeria] remained quite distinct culturally, commercially and administratively (Murray 1981: 147).

The geopolitical division of Nigeria into six zones did not go well with many Nigerians especially those from the south-east and those in north-central or the middle-belt. For example, a number of people in north-central Nigeria have agitated against being under the apparent leadership of the core-northern parts of Nigeria, they believe that Muslims in northern Nigeria have one goal and that is to Islamize the middle-belt and Nigeria at large. The adoption of the Sharia law by twelve states in northern Nigeria (Ruthfoss \& Joseph 2012:76), the inclusion of Nigeria as a member of the Organization of Islamic Conference in 1986, the introduction of Nigeria as a beneficiary of the Islamic Development Bank amidst protestation by Christians in 2005 (Ruthfoss \& Joseph 2010:43), the call by many Islamic clerics like Late Sheik Abubakar Gumi that
Christians should not be voted into power, and the impacts of many riots championed by Muslim extremists in northern Nigeria (Ruthfoss \& Joseph 2012:78-79) are a few among many reasons why Christians believe that the Muslims in Nigeria have a goal and that is to Islamize Nigeria. $^{6}$

\section{A Case Study of Jos Plateau}

On the cold night of $23^{\text {rd }}$ June, 2012, a traditional head of one of the renowned tourist centers of Nigeria in Kurra Falls was murdered allegedly by Hausa/Fulani jihadists. The sad incident happened in this manner: the late traditional ruler of Kurra Falls Da Thomas Gyang Jock while sleeping at night alongside his family members, some gun men suspected to be Hausa/Fulani forced themselves into the ruler's house and slaughtered the village head and his wife said one of his sons who escaped the attack. Furthermore, an accomplished Nigerian senator representing Plateau-North Senatorial District Gyang Dalyop Dantong, a member of Plateau state House of Assembly Honorable Gyang Fulani and many indigenous peoples of Plateau state were gunned down while attending a mass burial of 63 people most of whom belonged to the Berom ethnic group in July 2012. Dantong, Fulani, and the 63 individuals were all killed by suspected Hausa/Fulani jihadists. $^{7}$

In separate incidence, over 12 indigenous people of Barkin Ladi most of whom were Christians and of Berom ethnic group were slaughtered in the night and their property destroyed allegedly by Hausa/Fulani jihadists. The areas raided by these jihadists included Jong, Sunkut and Luhana allin Plateau state (Abdulsalami 2013). During the September 7, 2001, the $28^{\text {th }}$ November 2008, and $17^{\text {th }}$ January 2010 Christian-Muslim crises in Jos, hundreds of lives and property worth millions of dollars were lost (Je'adayibe \& Kudu 2013: 5-9). Many more religious crises in Jos Plateau have been going-on unnoticed and undocumented; many more lives lost as a result.

The most disturbing thing about many of the religious crises in Jos Plateau is that much arrest of especially Hausa/Fulani jihadists have been made yet government forces have always failed in carrying out any decisive action against the culprits. A member of the House of Representative from Plateau state Mr. Bitrus Kaze had at several occasions expressed concern were arrest of culprits

\footnotetext{
${ }^{6}$ Since 1960 till-date, 9 presidents from the north have ruled the country against 6 from the southern parts of Nigeria and only one Christian (Yakubu Gowon) from the north had ever ruled Nigeria, this and many other reasons makes the people in north-central to agitate for their independence from Muslims in the core northern parts of Nigeria who have always been at the hem of Nigeria's politics. The coup by Major Gideon Orkar in April, 1990 was an attempt to check the excessive control over the middle-belt by Muslims from the northern parts of Nigeria and by some Muslims in the middle-belt.

7"Breaking News: Plateau State Politicians, Gyang Dantong and Gyang Fulani, Killed After Attending Mass Burial of Victims of Saturday Attacks," $8^{\text {th }}$ July, 2012 from file://F:/1392-breaking-news-plateau-state-politicians-gyangdantong-and-gyang-fulani..
} 
were made yet no serious action has ever been taking against them rather they were set free after being taking to the Police headquarters in Jos and in Abuja. At several occasions, security personals who were supposed to protect the civilians had been arrested for rather aiding the activities pioneered by jihadists (Obateru 2011). There is growing suspicion among many Nigerians that its polity including the security agencies of the country has been infiltrated by Islamic jihadists. Chollom (2009:1-5) describes the Jos Plateau crisis as a "grand design by Hausa/Fulani to subdue Plateau State as the continuation of their Jihad." Why is Jos a special target for Islamic jihadists?

Jos is the capital of Plateau state and is one of the most important regions of the middle-belt or north-central Nigeria. The city of Jos is economically viable and has so far attracted numerous settlements of various groups of people in Nigeria and from the west mostly due to the discovery of tin since $1902 .^{8}$ The weather in Jos is one of coldest and most moderate weather in Nigeria. Je'adayibe \& Kudu describe Jos as "one of the healthiest places in West Africa." The plateaus and the vastly distributed mountains in Jos add to its beauty (cf. Je'adayibe \& Kudu 2013:3) hence "the home of peace and tourism" as popularly known. The commercial and climatic viability of Jos together with the receptive attitudes of the indigenous peoples of Jos has continued to attract national and global attention over the uniqueness of Jos-Plateau. Many Christian organizations like: Sudan Interior Mission, Evangelical Church of West Africa, Church of Christ in Nigeria and many more have established their administrative headquarters in Jos. Jos has informally been described as the Christian headquarters of Nigeria or the "Jerusalem" of Nigeria. The popular and late Nigerian Evangelist Paul Gindiri often abbreviated (JOS) to mean "Jesus Our Savior."9

The fact that Oldovai stone tools have been found in some parts of Jos Plateau and particularly on Berom lands suggests that early humans like Homo erectus might have lived in Jos and the much cherished conducive climate of Jos is a supporting factor to this suggestion. ${ }^{10}$ The immediate remnants of these early humans who continued to occupy Jos is not known but history reveals that the

\footnotetext{
${ }^{8}$ In the early $20^{\text {th }}$ century, Nigeria became the sixth largest producer of tin in the world with the greatest part of it emerging from Jos (Je'adayibe \& Kudu 2013:3).

${ }^{9}$ The city of Jos is having the highest name-slogans in Nigeria mainly because of it significance to all sundry. Some of the name-tag for Jos include "melting pot of ethnic nationalities," "Tin City," the "microcosm of Nigeria," "the nerve centre of Christian evangelism in Nigeria," and many more (Rothfuss \& Joseph 2010:48)

${ }^{10}$ Omolewa (2008:15) confirmed that early stone tools used for hunting have been found in certain parts of Jos-Plateau. For example, at Mai Idon Toro, two layers of gravels $(11 \mathrm{~m}$. above present river level) separated by a clay layer have been found to have produced cleavers. Also, at Pingell, on the northern region of Jos-Plateau more bifaces as cleavers were found and the cleavers might have been used by early humans like the Homo sapiens or the Neanderthal man over 65,000 ago (cf. Shaw 2004:26-27). There is yet to be found human fossils which supports the view that early humans (homo Neanderthal or Homo erectus) lived in Jos.
}

geographical and cultural association of Jos with the Nok culture suggests that Jos might have been occupied by humans sometime before 500 BCE (cf. Shaw 2004:26-27). Contemporary history indicates that since the 1900s, there were indigenous tribes (Berom, Anaguta, Jarawa and Afizere) ${ }^{11}$ living in Jos and subsistence farming was their main occupation in addition to tin mining amongst especially the Berom people. Hausa/Fulani ethnic group came to Jos strictly for commercial activities and some of them decided to settle in Jos Plateau when tin was no more Nigeria's main stay of economy. The Hausa/Fulani began to seek for the religious and political domination of JosPlateau but they were resisted by indigenous peoples of Jos. The creation of Jos-North local government in Plateau state in 1991 by General Ibrahim Babangida, a former president of Nigeria who is a Muslim was aimed at officially and forcefully giving the Hausa/Fulani an ownership of Jos. Je'adayibe \& Kudu (2013:5) says that this action carried out by Babangida has created discord between the Hausa/Fulani and the indigenous peoples of Jos while Chollom (2009) described the act as illogical simply because the indigenes were not consulted before the creation of the new local government.

Many citizens of Jos-Plateau and others have often reiterated that Islam will never take over Jos and its people. They cited that Uthman dan Fodio the founder of Islamic Jihad in Nigeria and his immediate successors have made several attempts to Islamize Jos, yet they were unsuccessful. Isichei (1982:227-228) suggest that dan Fodio and his successors who fought for Jihad on horses and chariots could not penetrate Jos because of the rocky-plateau topography which was unsuitable for their horses to trail on. The tribal people of Jos also had their traditional beliefs hence it was irrelevant for them to accept Islam. Rothfuss \& Joseph (2010:49) say that:

The majority of the autochthonous ethnic groups of the Middle Belt, particularly around the Jos Plateau, resisted the Islamic proselytisation. Thus the Middle Belt provided safe havens for many people, including even the HausaFulani, who were escaping from the invading forces of the Jihad.

This researcher is of the opinion that the Hausa/Fulani peoples are not the original owners of Jos for the following reasons:

- $\quad$ history suggest that the Fulani people were originally settlers in Hausa land and that was why they could not enjoy the same privileges as the Hausas until dan Fodio used Jihad and persuasion to win victory over the Hausas. The Islamic Jihad in Nigeria is sometimes referred to as Fulani Jihad. The Bukhari revolt, the Mafara revolt, the Yusuf revolt, and several Mahdist revolts were all attempts by previous Hausa rulers to check the influence of Fulani leadership in Hausa land (cf. Omolewa 2008:122). The acceptance of Jihad and Islam by many Hausas in Hausa land brought some

\footnotetext{
${ }^{11}$ (cf. Rothfuss \& Joseph 2010:50).
} 
kinds of compromise of unity between the Fulani and the Hausas and this kind of cooperation made the Hausa/Fulani people to begin to fight for the control of Jos and other states in the middle-belt.

- At present, there is not specific area traditionally owned by the Hausa/Fulani in Jos. The Berom, Naraguta, Jarawa and Afizere have specific boundaries allotted to them by their ancestors in Jos and these demarcations have been traditionally approved by the previous governments of Nigeria.

- Islamic or dan Fodio's Jihad seemingly sanctions domination and control of areas where Muslims gradually acquire a reasonable population size. The quest by the Hausa/Fulani to own Jos-Plateau may be in fulfillment of Islamic tenets which allow the capturing and control of certain territories (cf. The Holy Qur'an, chapter 2 verses 190,191). ${ }^{12}$

\section{Conclusion}

The indigenous peoples of Jos are known for their receptive attitudes towards visitors and their enculturation with their guests. For example, many streets in Jos have been named after non-indigenous peoples hosted in JosPlateau some of which are Oyewumi, Adetutu streets (Yoruba names); Ojukwu Street (Ibo name); Ali Kazaure (Hausa name) and many more. These names are aimed at showing the good nature of friendship that exists between the people of Jos and all those that live in it. The tension that exists between the indigenous peoples of Jos and the Hausa/Fulani is that the Hausa/Fulani people do not only want to live in Jos but they want to rule and dominate the political and religious affairs of the state. The so-called ethno-religious crises in Jos may be checked or stopped if the Hausa/Fulani communities in Jos accept to live like the Ibos, Yoruba, Tivs, and many tribes who are living in Jos. These peoples do not claim any form of ancestral ownership of Jos so is expected of the Hausa/Fulani. In the history of Nigeria, there is yet to be a chiefdom or a local government owned and chaired by Ibo or Yoruba tribal group in Kano, Kastina and Zamfara which are regarded as Hausa states neither is there any Hausa chiefdom in Enugu, Imo, Edo and other states in southern Nigeria; and if this has been the trend of Nigerian history, why should the Hausa/Fulani keep demanding for the control of JosPlateau apart from course of furthering Islamic Jihad? Therefore, the conflicts between the Muslims and Christians in Jos-Plateau are purely to enhance the course of Islamic jihad hence religious conflict.

Recommendation: Humans would continue to have different views about religion, culture, politics and even economics. What is most pertinent at this point for all human beings irrespective of their beliefs is to learn to

\footnotetext{
${ }^{12}$ Uthman dan Fodio called on his followers to use force to take over lands occupied by infidels, Dar al-Harb and turn those lands into the lands of the faithful Dar al-Islam (Omolewa 2008:116).
}

accept one another and to live together as humans. The Nigerian government needs to channel more of her resources and energy in educating her people on tolerance and respect for all Nigerians despite their varied belief systems.

\section{References}

[1] Abdulsalami Isa., 2011, "Gunmen kill 12 in Plateau," The Guardian. January 28 ${ }^{\text {th }}$, 2011. From www.theguardiannigerianonline.mhtml viewed $25^{\text {th }}$ May 2013.

[2] Adamu Theresa., 2002, lectures on "Christianity and Islam from 622-1453," Bukuru, The Theological College of Northern Nigeria, $10^{\mathrm{TH}}-19^{\mathrm{TH}}$ March 2002.

[3] Agai Jock Matthew., 2003, lectures on "The effects of poor relationship between Christians and Muslims: The way forward," Bukuru, The Theological College of Northern Nigeria, $16^{\text {th }}$ April 2003, pp.1-9.

[4] Ali, Abdullah.Yusuf., 1938, The Holy Qur-an Text, translation and commentary, SH Muhammad Ashraf: Lahore.

[5] Aliogo, E. Jonathan., 2012,Up to date current affairs, Dejoe Publication: Enugu.

[6] "Breaking News: Plateau State Politicians, Gyang Dantong and Gyang Fulani, Killed After Attending Mass Burial of Victims of Saturday Attacks," $8^{\text {th }}$ July, 2012 on file://F:/1392-breaking-news-plateau-state-politiciansgyang-dantong-and-gyang-fulani... viewed $27^{\text {th }}$ June 2013.

[7] "Muhammed Bello.," Viewed 24rd June 2013. From www.thefreeencyclopedia.htm

[8] Chollom, Ezekiel., 2009, "Re: How Jos Crisis Erupted, By Reps C'ttee" News diary on www.joscrisis.mht $9^{\text {th }}$ April 2009, viewed $26^{\text {th }}$ June 2013.

[9] Je'adayibe Gwamna Dogara., \& Kudu Amango., 2013, "Sliding towards Armageddon: Revisiting ethno-religious crises in Nigeria" from www.abriefhistoryofjos.mhtm viewed $6^{\text {th }}$ May 2013, pp. 1-27.

[10] Falola, Toyin. \& Heaton, M. Matthew., 2010, A history of Nigeria. Cambridge University Press: Cambridge.

[11] Isichei, Elizabeth., (ed.), 1982. Studies in the history of Plateau state. London: Macmillan Press.

[12] Lange, Dierk., 2004, Ancient kingdoms of West Africa: Africa-centred and Canaanite-Israelite perspectives, a collection of published and unpublished studies in English and French, J.H.Roll: Dettelbach.

[13] Lavers, E. John., 2004, 'Kanem and Borno to 1800 'in O. Ikime (ed.) Groundwork of Nigerian history, Heinemann Educational Books: Jos, pp. 187-209.

[14] Major Gideon Okar Coup Speech in April 1990 on mhtml:file://F:/Major-Gideon-Okar-Coup-Speech , viewed $27^{\text {th }}$ June 2013.

[15] Muhaiyadden, M.R. Bawa., 1990, Islam and world peace: Explanation of the Sufi, The Fellowship Press: Philadelphia. 
[16] Murray, Jocelyn., 1981 (ed.), Cultural atlas of Africa, Oxford Press. Phaidon.

[17] Nasr, Seyyed Hossein., 2006, "Al-Serat: The spiritual significance of Jihad," vol. IX, No.1 on www.thespiritualsignificanceofjihad.htm viewed $29^{\text {th }}$ March 2006.

[18] Obateru, Taye., 2011, "Jos: Crisis: Failure to prosecute sponsors worried Rep,"The Vanguard. January $19^{\text {th }} 2011$. From www.vanguardnigeriaonlineedition. mhtml viewed $26^{\text {th }}$ June 2013.

[19] Omolewa, Michael., 2008, Certificate history of Nigeria. Longman: Ikeja.

[20] Shaw, Thurstan., 2004, 'Prehistory', in O. Ikime (ed.).
Groundwork of Nigerian history, Heinemann Educational Books: Jos, pp. 25-53.

[21] Rothfuss, Rainer. \& Joseph, Yakubu., 2010, "The Spatial Dimension of Muslim-Christian Conflict in the Middle Belt of Nigeria”, International Journal for Religious Freedom, $3: 2,2010$, pp. 39-63.

[22] Rothfuss, Rainer. \& Joseph, Yakubu., 2012, "Threads to Religious Freedom in Nigeria", International Journalfor Religious Freedom, 5:2, 2012, pp. 73-85.

[23] Skolfield, H. Ellis, 2001, The false prophet: Who is behind Middle East terrorism? Fish House Publishing: Florida.

[24] Sookhdeo, Patrick., 2002, A Christian pocket guide to Islam, Christian Focus \& Isaac Publishers: Scotland. 